of diffractometers. In a section on crystal physics, surely an attempt should be made to justify the indicatrix. Part two begins with an interesting account of crystallization processes and phaso diagrams up to terraries; it then leads on to hydrous systems. The sections on igneous and metamorphic petrology are much too condensed, but the account on the role of volatiles is quite the best to appear in an elementary text. There are further chapters on sedimentary rocks, metasomatism, the development of tectonites, and geochemistry.

The account seems to have lost little in translation, the diagrams are excellent and the paper, although still of two types, is of good quality. A bibliography is provided as well as author and subject indexes. 'The work throughout is written with authority and reaches a high standard, but one is left with the feeling that this vast field would have been covered much better by two books.

I. D. MUIR

\section{OPTICS FOR UNDERGRADUATES}

\section{University Optics}

Vol. 1. By D. W. Tenquist, R. M. Whittle and J. Yarwood. Pp. viii +349 . (Iliffe: London, October 1969.) $70 s$.

Is the preface the authors describe this text as "intended to cover the requirements in the subject of optics for the student preparing for Part 1 of an honours degree in physics, a general degree in science or ancillary physics to an honours degree in chemistry or other main discipline". Of the material covered in volume one, the first three chapters deal with geometrical optics and optical instruments. These chapters deal with these difficult subjects clearly and concisely. Refractometry and photometry take up nearly one-third of the volume and it is this extensive treatment of practical optics which distinguishes this book from the many other available texts. The velocity of light is given a chapter to itself, which seems a little excessive. The wave theory of light is followed by sections on interference, diffraction and resolving power.

There are worked examples throughout the text and questions from various university degree examinations are included at the end of each chapter, with answers to the numerical problems at the end of the book. The treatment, throughout is traditional, in contrast with other recent undergraduate books in optics. While there is nothing particularly novel in either presentation or material, the writing is thorough and accurate. Special attention is paid to practical details, particularly in those sections dealing with optical measurements and instruments. There are plenty of clear, well-drawn diagrams which supplement the text, but it is a pity that the publisher did not choose a better quality of paper.

To sum up, this is a useful book which, while suitable for applied physics and ancillary physics courses, probably does not present sufficient challenge for a first year undergraduate intending to specialize in physics.

D. J. BRADLEY

\section{Obituaries}

\section{Mrs M. J. Richards}

MrS M. J. RichaRDS (Dr Maud Norris) will be remembered chiefly for her work as a locust entornologist, in which she had a world-wide reputation. It was Mrs Richards who discovered the maturation pheromone of the desert locust in 1954. Her association with locusts and the Anti-Locust Research Centre came about almost by accident and in spite of the fact that her early work had been on pests of stored products. When the Anti-Locust
Research Centre became an independent research institute in 1945, the director at that time, Dr B. P. (now Sir Boris) Uvarov, was looking for a scientist to run the laboratory. Mrs Richards expressed interest, was given a research grant in 1946 and from then until December 1969 never gave up locust work.

Maud Richards was born in Plymouth in 1907, the daughter of a naval officer, and was educated at several schools including Cheltenham Ladies' College. At King's College, London, she obtained first class honours in zoology in 1928. She became a demonstrator at King's College and then held a DSIR grant in the Department of Zoology and Applied Entomology of Imperial College, where sho obtained her $\mathrm{PhD}$ degree. It was also here that she met her husband, Professor O. W. Richards, who was then a lecturer in the department, and she was married in 1931. From 1932-34 she was a research assistant at Imperial College and took up what was to remain the major theme of all her work, the reproductive processes and associated behaviour of insects. Her three papers on the stored products moth Ephestia, published in 1932, 1933 and 1934 and still quoted today, typify her broad approach and include studies of the structure and functions of the reproductive organs, the effect of food and external factors, and physiology.

After 1934, when she stopped working full time, she did part time work in the British Museum (Natural History) on the Zoological Record as well as voluntary work at the Pest Infestation Laboratory in Slough. In 1937 she accompanied her husband to British Guiana, sharing his Leverhulme grant, to collaborate on the biology of social wasps; a notable joint paper resulted later. In 1946 Mrs Richards joined the ALRC as a research fellow, was then appointed an SSO and finally promoted to PSO, which she remained until her death this year. While there she published more than twenty-five important papers on locust biology and physiology, and built up an international reputation for her work on the effects of grouping and phases in locust biology. She made important observations on the effects of density, food and photoperiod on locust reproduction and maturation, but clearly something else more elusive was involved and in 1954 her patience and persistence were rewarded with the discovery of a chemical influence, the maturation pheromone. This was a finding of great importance and was one of the first demonstrations that this type of eompound existed.

Mrs Richards's research stimulated further work in the ALRC and in many other laboratories in this field, resulting directly in the discovery of more pheromones. She herself found others connected with reproduction and, recently, a chemical functioning in gregarious oviposition behaviour of locusts. Indirectly her work generated interest in chemicals biologically active in locust reproduction, particularly plant chemicals that trigger maturation.

She was now well known internationally, and was awarded the DSc of the University of London in 1964. She was much in demand for international symposia, treating this recognition with characteristic modesty; she was also interested in field work overseas, enjoying these visits not only for the experience itself but because they provided her with insights for further laboratory work. During the 1960s she went abroad frequently. In probably the most interesting and arduous of her trips she and Professor Richards joined the Royal Society and Royal Geographical Society Expedition to the Mato Grosso in Brazil in 1968. She passed off the hardships of the life there with characteristic calmness and said that sho was much more interested in the great variety of grasshoppers that she found in the forest than in the difficulties of camp life.

Mrs Richards was one of the longest-serving members of the Anti-Locust Research Centre; she had a quiet, friendly, unassuming manner and never sought the limelight. But she could be roused when scientists, be they 